\title{
Low Dose Weekly Paclitaxel Versus Low Dose Weekly Cisplatin with Concomitant Radiation in Locally Advanced Head and Neck Cancers
}

\author{
Rasha Hamdy Hamed* and Eman Elzahaf \\ Department of Clinical Oncology and Nuclear Medicine, Faculty of Medicine, Mansoura University, Dakhlia, Egypt
}

\begin{abstract}
Purpose: The purpose of this prospective phase III study was to compare the role of concomitant chemoradiation using paclitaxel versus cisplatin in locally advanced head and neck cancers.

Patients and methods: 52 patients were randomly assigned to one of the two concomitant chemoradiation arms: arm I $(n=26)$ and arm II $(n=26)$ who received injection of paclitaxel $20 \mathrm{mg} / \mathrm{m}^{2} \mathrm{I} / \mathrm{V} 1$ hour infusion before radiation, repeated weekly for 6 cycles, and cisplatin $30 \mathrm{mg} / \mathrm{m}^{2} \mathrm{I} / \mathrm{V} 1$ hour infusion before radiation, repeated weekly for 6 cycles, respectively. The planned radiotherapy dose was 66-70 Gy, 1.8-2 Gy/day, 5\#/Week in 6-7 weeks.

Results: Response rates were 76 and $69.2 \%$ in arm I and arm II, respectively $(P=0.53)$. The hematologica toxicity was generally mild. On the contrary, non-hematologic toxicities were severe. Grade III mucositis occurred in $32 \%$ in arm I and in $23.1 \%$ in arm II (P = 0.04). Moreover, grade III dermatitis were encountered in $28 \%$ in arm I and $11.5 \%$ in arm II $(P=0.03)$. The 2-year local-regional control figures were 60 and $57.1 \%$ in arm I and arm II, respectively $(\mathrm{P}=0.52)$; however the 2-year progression-free survival figures were 36.8 and $33.3 \%$ in arm I and arm II, respectively $(P=0.43)$, while the 2-year overall survival figures were 56 and $50 \%$ in arm I and arm II, respectively $(P=0.68)$
\end{abstract}

Conclusion: Both concomitant chemoradiotherapy regimens were easily given in the outpatient clinic. The regimen based on paclitaxel was more effective; however, the difference was insignificant.

Keywords: Concomitant chemoradiotherapy; Cisplatin; Paclitaxel; Head and neck cancer

\section{Introduction}

Head and neck cancer constitutes a heterogeneous group of malignancies which exceeds half a million cases annually, ranking it as the fifth most common cancer worldwide. Head and neck cancer accounts for about $3 \%$ to $5 \%$ of all cancers in the United States [1]. It represents $17 \%$ of all malignant tumours in Egypt [2].

The treatment of patients with unresectable, locally advanced head and neck squamous cell carcinoma (HNSCC) remains a challenge. Radiation has been the standard treatment for locally advanced, unresectable HNSCC.Even the most effective radiotherapy regimens result in local control rates not exceeding 50-70\% and diseasefree survival rates not more than $30-40 \%$. This circumstance has stimulated the investigation of treatments combining radiotherapy and chemotherapy ; the most promising approach being the administration of chemotherapy concurrent with radiation [3]. A number of randomized studies have shown improved results when radiation was combined with concurrent cytotoxic agents compared with radiation alone despite increased toxicity of the combined arm, notably hematological and mucosal toxicities, which limited the ability to deliver full doses of radiation or the chemotherapeutic agents [48]. Although most trails of concurrent chemoradiation have used cisplatin in combination with 5-fluorouracil (5-FU), there is at present no evidence that this combination performs better than cisplatin alone [9]; thus, the optimal drugs, doses and schedules of concurrent chemotherapy and radiotherapy for head and neck cancer are not known.

We used cisplatin arm as a control arm because cisplatin is one of the most extensively used agents effective in the management of squamous cell carcinoma of head and neck which can be used either as a single agent or combined with a variety of other drugs and has shown improved overall response rate up to [10].
Paclitaxel is a newer active single agent in head and neck cancer,it was used in the trial arm in low dose weekly schedule. Observation suggests that paclitaxel induces microtubule stabilization, and a cell cycle blockade at the $\mathrm{G} 2$ phase to mitosis $(\mathrm{G} 2 / \mathrm{M})$ transition, the most radiosensitive portion of the cell cycle $[11,12]$. An additional mechanism seems to involve enhanced tissue oxygenation. Recently it was shown that paclitaxel activates c-Jun-terminal-kinase (JNK) or protein-kinase A (PKA), leading to the phosphorylation of the antiapoptotic $\mathrm{Bcl}-2$ protein. Phosphorylation of $\mathrm{Bcl}-2$ decreases its binding to the proapoptotic Bax protein and an increase in the free Bax level promotes apoptosis [13]. This apoptotic effect of paclitaxel is independent of the p53 pathway [14]

Keeping this in mind in our setting we planned to compare the role of concomitant chemoradiation using paclitaxel versus cisplatin in locally advanced head and neck cancers.

\section{Patients and Methods}

Between January 2009 and June 2010, 52 patients with locally advanced squamous cell carcinoma of head and neck who attended to Clinical Oncology and Nuclear Medicine Department, Mansoura

*Corresponding author: Rasha Hamdy Hamed, MD, Department of Clinica Oncology and Nuclear Medicine, Faculty of Medicine, Mansoura University, Egypt; Tel:0020102655067; Fax: 0020502249934; E-mail: rashahamdy22@yahoo.com

Received July 21, 2011; Accepted August 28, 2011; Published September 14 2011

Citation: Hamed RH, Elzahaf E (2011) Low Dose Weekly Paclitaxel Versus Low Dose Weekly Cisplatin with Concomitant Radiation in Locally Advanced Head and Neck Cancers. J Cancer Sci Ther 3: 168-172. doi:10.4172/1948-5956.1000082

Copyright: () 2011 Hamed RH, et al. This is an open-access article distributed under the terms of the Creative Commons Attribution License, which permits unrestricted use, distribution, and reproduction in any medium, provided the original author and source are credited. 
University Hospital, were randomly assigned in this prospective phase III study.

\section{Eligibility criteria}

Patients with biopsy proven HNSCC stages III and IV tumors for all sites were eligible. Patients must have been either ineligible for curative resection or have refused surgery and must have had no prior radiotherapy to the head and neck region or chemotherapy. Patients with obvious metastatic disease on diagnostic imaging were excluded from the study. Additional eligibility criteria included the following: eastern co-operative oncology group (ECOG) performance status $\leq$ 2 , age greater than 18 years, absolute granulocyte count greater than $2000 / \mathrm{mm}^{3}$, platelet count greater than $100,000 / \mathrm{mm}^{3}$, serum bilirubin, SGOT, SGPT, serum creatinine within normal limit, no other history of active malignancy and no other serious medical disease.

\section{Pretreatment evaluation}

Pretreatment evaluation included complete history, physical examination, head and neck examination including mirror and panendoscopic examination, histopathologic examination of the primary tumor or cervical lymph nodes, complete blood count, blood chemistry including liver function tests, and kidney function, computed tomography and or magnetic resonance imaging of the head and neck to define the extent of the disease and metastatic workup including chest $\mathrm{x}$-ray and imaging of liver by ultrasound or computed tomography in all patients. Bone scan was not routinely performed and was restricted to those with bone pain or elevated serum alkaline phosphatase. Dental care was applied to each eligible patients before therapy.

\section{Treatment schedule}

All patients were treated on a linear accelerator or cobalt - 60 teletherapy unit. Patients of both arms received a total dose of 66-70 Gy radiation, $200 \mathrm{cGy/day,} \mathrm{5 \# /Week} \mathrm{in} \mathrm{6-7} \mathrm{weeks.} \mathrm{Arm} \mathrm{I} \mathrm{patients}$ received concurrent dose of paclitaxel $20 \mathrm{mg} / \mathrm{m}^{2} \mathrm{I} / \mathrm{V} 1$ hour infusion with premeditation 4-6 hours before radiation, repeated weekly for 6 cycles. Arm II patients received concurrent dose of cisplatin $30 \mathrm{mg} /$ $\mathrm{m}^{2} \mathrm{I} / \mathrm{V} 1$ hour infusion with full hydration 4-6 hours before radiation, repeated weekly for 6 cycles.

During the study, patients were hospitalized and given symptomatic treatment as needed. Patients were reviewed every week and assessed with complete clinical examination including indirect laryngoscopy and in addition, were evaluated for toxicities according to RTOG acute radiation morbidity scoring criteria. Systemic toxicities were graded according to the common toxicity criteria, version 2 . Laboratory and clinical toxicities were considered acute if discovered during the first 12 weeks after the initiation of therapy.

\section{Post-treatment evaluation}

Response was assessed six weeks after completion of radiotherapy by clinical examination, endoscopic examination, and CT and/or MRI of head and neck. Criteria for response were as follows: complete response (CR) was defined as complete regression of all evidence of tumor. Partial response (PR) was defined as an estimated decrease in tumor size of $50 \%$ or more. Stationary disease (SD) was defined as $<50 \%$ decrease in tumor size or $<25 \%$ increase in pretreatment tumor size. Progressive disease (PD) was defined as $>25 \%$ increase in pretreatment tumor size.
Re-evaluation was done at 3 months interval during the first two years of follow-up unless any manifestations of progression were developed. Chest radiography and ultrasonography of the liver were performed every 6 months.

\section{End points}

The primary endpoints were to analyse and compare locoregional control and acute adverse effects in both treatment arms. The secondary endpoints were to analyse and compare progression-free survival and overall survival in both treatment arms.

\section{Statistical methods}

All data were categorical and represented as number and percent. The baseline characteristics and adverse effects of the two treatment arms were compared using the Chi-square test. Confidence intervals (CIs) were calculated using Cox's proportional hazard model. Overall survival, local-regional free survival and progression-free survival were calculated using the Kaplan-Meier method. Mann-Whitney U test used to compare the median responses, overall survival, local-regional free survival and progression-free survival in both treatment groups.

Prognostic factors related to response, overall survival, localregional free survival and progression- free survival were assessed using Cox proportional hazards regression model.

Informed consent was obtained from all patients, and ethical committee approval was received by our participating center.

The randomization scheme was a permuted block design with an equal probability of assignment to either treatment arms. Patients were stratified by primary site of disease and stage of disease and were then randomized to receive one of the two treatments planned in the trial.

\section{Results}

\section{Patient's characteristics}

From January 2009 to June 2010, 52 patients were recruited and randomly assigned into two treatment arms, either arm I with 26 patients or arm II with 26 patients. . Data of one case was deleted list wise in arm I because he could not be subsequently contacted. A total of 51 patients received complete treatment as defined per protocol or with an acceptable variation with respect to overall days of therapy and total dose.

Table 1 shows the pre-treatment patients characteristics. They were well balanced among the both treatment groups. The median age was 58 years, ranging from 20 to 70 years. Males were predominant representing $76.5 \%, 60.8 \%$ of our patients were smokers. The nasopharynx was the most common primary site representing $39.2 \%$. All patients were stage III (41.2\%) and stage IV (58.8\%).

\section{Response}

Response assessment was done 6 weeks after the completion of treatment. The overall response rates were $76 \%$ (95\% CI, $0.564-0.884)$ and $69.2 \%$ (95\% CI, $0.498-0.835)$ respectively for arm I and arm II, with no statistically significant difference $(\mathrm{p}=0.58)$. Complete response were achieved in $60 \%$ of patients in arm I versus $53.8 \%$ for arm II but the difference was statistically insignificant $(\mathrm{P}=0.66)$. Partial response was achieved in $16 \%$ versus $15.4 \%$ in arm I, II respectively $(\mathrm{p}=0.95)$ (Table 2). 


\begin{tabular}{|c|c|c|c|c|c|c|c|}
\hline \multirow[t]{2}{*}{ Character } & \multicolumn{2}{|c|}{ Total } & \multicolumn{2}{|c|}{ Arm I } & \multicolumn{2}{|r|}{ Arm II } & \multirow[t]{2}{*}{ P Value } \\
\hline & No. & $\%$ & No. & $\%$ & No. & $\%$ & \\
\hline $\begin{array}{l}\text { Age (years): } \\
<60 \\
\geq 60\end{array}$ & $\begin{array}{l}31 \\
20\end{array}$ & $\begin{array}{l}60.8 \\
39.2\end{array}$ & $\begin{array}{l}15 \\
10\end{array}$ & $\begin{array}{l}60 \\
40\end{array}$ & $\begin{array}{l}16 \\
10\end{array}$ & $\begin{array}{l}61.5 \\
38.5\end{array}$ & 0.9104 \\
\hline $\begin{array}{l}\text { Sex: } \\
\text { Male } \\
\text { Female }\end{array}$ & $\begin{array}{l}39 \\
12\end{array}$ & $\begin{array}{l}76.5 \\
23.5\end{array}$ & $\begin{array}{l}20 \\
5\end{array}$ & $\begin{array}{l}80 \\
20\end{array}$ & $\begin{array}{l}19 \\
7\end{array}$ & $\begin{array}{l}73.1 \\
26.1\end{array}$ & 0.56 .01 \\
\hline $\begin{array}{l}\text { Smoking: } \\
\text { Smoker } \\
\text { Non smoker }\end{array}$ & $\begin{array}{l}31 \\
20\end{array}$ & $\begin{array}{l}60.8 \\
39.2\end{array}$ & $\begin{array}{l}15 \\
10\end{array}$ & $\begin{array}{l}60 \\
40\end{array}$ & $\begin{array}{l}16 \\
10\end{array}$ & $\begin{array}{l}61.5 \\
38.5\end{array}$ & 0.9104 \\
\hline $\begin{array}{l}\text { ECOG score } \\
1 \\
2 \\
\end{array}$ & $\begin{array}{l}31 \\
20\end{array}$ & $\begin{array}{l}60.8 \\
39.2\end{array}$ & $\begin{array}{l}15 \\
10\end{array}$ & $\begin{array}{l}60 \\
40\end{array}$ & $\begin{array}{l}16 \\
10\end{array}$ & $\begin{array}{l}61.5 \\
38.5\end{array}$ & 0.9104 \\
\hline $\begin{array}{l}\text { Site: } \\
\text { Oral cavity } \\
\text { Nasopharynx } \\
\text { Oropharynx } \\
\text { Hypopharynx } \\
\text { Larynx }\end{array}$ & $\begin{array}{l}5 \\
20 \\
6 \\
10 \\
10\end{array}$ & $\begin{array}{l}9.8 \\
39.2 \\
11.8 \\
19.6 \\
19.6\end{array}$ & $\begin{array}{l}2 \\
12 \\
2 \\
4 \\
5\end{array}$ & $\begin{array}{l}8 \\
48 \\
8 \\
16 \\
20\end{array}$ & $\begin{array}{l}3 \\
8 \\
4 \\
6 \\
5\end{array}$ & $\begin{array}{l}11.5 \\
30.8 \\
15.4 \\
23.1 \\
19.2\end{array}$ & $\begin{array}{l}0.6709 \\
0.2076 \\
0.4132 \\
0.5245 \\
0.9448\end{array}$ \\
\hline $\begin{array}{l}\text { Grade } \\
\text { I } \\
\text { II } \\
\text { III } \\
\text { Undifferentiated }\end{array}$ & $\begin{array}{l}11 \\
10 \\
12 \\
18\end{array}$ & $\begin{array}{l}21.6 \\
19.6 \\
23.5 \\
35.3\end{array}$ & $\begin{array}{l}5 \\
6 \\
5 \\
9\end{array}$ & $\begin{array}{l}20 \\
24 \\
20 \\
36\end{array}$ & $\begin{array}{l}6 \\
4 \\
7 \\
9\end{array}$ & $\begin{array}{l}23.1 \\
15.4 \\
26.9 \\
34.6\end{array}$ & $\begin{array}{l}0.7894 \\
0.4385 \\
0.5601 \\
0.9176\end{array}$ \\
\hline $\begin{array}{l}\text { T-stage } \\
\text { T2 } \\
\text { T3 } \\
\text { T4 }\end{array}$ & $\begin{array}{l}10 \\
31 \\
10\end{array}$ & $\begin{array}{l}19.6 \\
60.8 \\
19.6\end{array}$ & $\begin{array}{l}4 \\
16 \\
5\end{array}$ & $\begin{array}{l}16 \\
64 \\
20\end{array}$ & $\begin{array}{l}6 \\
15 \\
5\end{array}$ & $\begin{array}{l}23.1 \\
57.7 \\
19.2\end{array}$ & $\begin{array}{l}0.5245 \\
0.9104 \\
0.9448\end{array}$ \\
\hline $\begin{array}{l}\text { N-stage: } \\
\text { N0 } \\
\text { N1 } \\
\text { N2 } \\
\text { N3 }\end{array}$ & $\begin{array}{l}11 \\
11 \\
20 \\
9\end{array}$ & $\begin{array}{l}21.6 \\
21.6 \\
39.2 \\
17.6\end{array}$ & $\begin{array}{l}5 \\
4 \\
13 \\
3\end{array}$ & $\begin{array}{l}20 \\
16 \\
52 \\
12\end{array}$ & $\begin{array}{l}6 \\
7 \\
7 \\
6\end{array}$ & $\begin{array}{l}23.1 \\
26.9 \\
26.9 \\
23.1\end{array}$ & $\begin{array}{l}0.7894 \\
0.3430 \\
0.0667 \\
0.2995\end{array}$ \\
\hline $\begin{array}{l}\text { AJC stage: } \\
\text { III } \\
\text { IV }\end{array}$ & $\begin{array}{l}21 \\
30\end{array}$ & $\begin{array}{l}41.2 \\
58.8\end{array}$ & $\begin{array}{l}11 \\
14\end{array}$ & $\begin{array}{l}44 \\
56\end{array}$ & $\begin{array}{l}10 \\
16\end{array}$ & $\begin{array}{l}38.5 \\
61.5\end{array}$ & 0.6878 \\
\hline
\end{tabular}

Table 1: Patient Characteristics.

\begin{tabular}{|c|c|c|c|c|c|}
\hline \multirow[t]{2}{*}{ Response } & \multicolumn{2}{|c|}{ Arm I } & \multicolumn{2}{|c|}{ Arm II } & \multirow[t]{2}{*}{ P Value } \\
\hline & No. & $\%$ & No. & $\%$ & \\
\hline Complete response & 15 & 60 & 14 & 53.8 & 0.6573 \\
\hline Partial response & 4 & 16 & 4 & 15.4 & 0.9518 \\
\hline Stationary disease & 3 & 12 & 4 & 15.4 & 0.7254 \\
\hline Progressive disease & 3 & 12 & 4 & 15.4 & 0.7254 \\
\hline Overall response & 19 & 76 & 18 & 69.2 & 0.5881 \\
\hline
\end{tabular}

Table 2: Response.

\section{Toxicity and treatment compliance}

As regard toxicity, toxicity was higher in the paclitaxel group but it was tolerable and manageable. Table 3 show the site and grade of acute effects by treatment groups. The most common sites of grade 3 or worse acute side effects were the skin and the mucous membranes. Compared to arm II, arm I had significantly increased grade 3 or worse acute side effects as dermatitis $(\mathrm{P}=0.03)$, mucositis $(\mathrm{P}=0.04)$.

\section{Survival}

The median local recurrence free survival was 17 months (ranging from 6-26 months) in arm I versus 15 months (ranging from 3-26 months) in the arm II. Locoregional control rate at two years was (60\%) in arm I compared with (57.1\%) in arm II but the difference was statistically insignificant $(\mathrm{P}=0.52)$. Results of Kaplan- Meier estimates of local-regional control in both treatment groups are shown in Figure 1.
Progression includes the following events: local, regional, locoregional and distant failure. The median progression-free survival was 11 months (ranging from 3-26 months) in arm I vs 9 months (ranging from 2-26 months) in arm II ( $\mathrm{P}=0.43)$. In addition, 2-year progressionfree survival in arm I $36.8 \%$ vs $33.3 \%$ in arm II, with statistically insignificant difference $(\mathrm{P}=0.28)$, (Figure 2).

At a median follow-up of 20 months of all analyzed patients, the median overall survival in arm I was 19 months( ranging from 7-26 months) vs 17 months( ranging from 5-26 months) in arm II, with no statistically significant difference $(\mathrm{P}=0.16)$. The 2 -year overall survival in arm I was $56 \%$ vs $50 \%$ in arm II, with no statistically significant difference ( $\mathrm{P}=0.68)$, (Figure 3 ).

\section{Pattern of treatment failure}

The primary site was the most common location of treatment 
Citation: Hamed RH, Elzahaf E (2011) Low Dose Weekly Paclitaxel Versus Low Dose Weekly Cisplatin with Concomitant Radiation in Locally Advanced Head and Neck Cancers. J Cancer Sci Ther 3: 168-172. doi:10.4172/1948-5956.1000082

failure. The 2-year locoregional failure rates were $40 \%$ in arm I vs $42.9 \%$ in arm II, $(\mathrm{P}=0.19)$. However, the incidence of distance metastases at 2 -years was $4 \%$ in arm I vs $7.7 \%$ in $\operatorname{arm}$ II $(\mathrm{P}=0.43)$.

\section{Prognostic factors}

On multivariate analysis for locoregional control, $\mathrm{T}$ category (T4 vs $\mathrm{T} 2, \mathrm{~T} 3$; $\mathrm{P}=0.03$ ), tumor site (oral cavity or oropharynx vs all other sites; $\mathrm{P}=0.04)$, and $\mathrm{N}$-category (N2-N3 vs $\mathrm{N} 0, \mathrm{~N} 1 ; \mathrm{P}=0.05)$,) were significant independent adverse prognostic factors for locoregional control. However, on multivariate analysis for progression- free survival, $\mathrm{T}$ category (T4 vs T2, T3; $\mathrm{P}=0.01$ ), sex (male vs female; $\mathrm{P}=0.024$ ) and smoker patients $(\mathrm{P}=0.03)$ had independent adverse prognostic impact on progression-free survival. In addition, on multivariate analysis for survival, sex $(\mathrm{P}=0.03)$, poor performance status $(\mathrm{P}=0.03), \mathrm{T} 4(\mathrm{P}=0.01)$, $\mathrm{N} 2-\mathrm{N} 3$ category $(\mathrm{P}=0.04)$ and stage IV $(\mathrm{P}=0.01)$ were independent factors associated with poor prognosis for survival.

\begin{tabular}{|c|c|c|c|c|c|c|}
\hline \multirow[t]{2}{*}{ Organ/Tissue } & \multirow[t]{2}{*}{ Grade } & \multicolumn{2}{|c|}{ Arm I } & \multicolumn{2}{|c|}{ Arm II } & \multirow[t]{2}{*}{ P Value } \\
\hline & & No. & $\%$ & No. & $\%$ & \\
\hline Anemia & $\begin{array}{l}1 \\
2\end{array}$ & $\begin{array}{l}8 \\
8\end{array}$ & $\begin{array}{l}32 \\
32\end{array}$ & $\begin{array}{l}9 \\
8\end{array}$ & $\begin{array}{l}34.6 \\
30.8\end{array}$ & 0.8658 \\
\hline Leucopenia & $\begin{array}{l}1 \\
2\end{array}$ & $\begin{array}{l}8 \\
7\end{array}$ & $\begin{array}{l}32 \\
28\end{array}$ & $\begin{array}{l}7 \\
8\end{array}$ & $\begin{array}{l}26.7 \\
30.8\end{array}$ & 0.7150 \\
\hline Thrombocytopenia & $\begin{array}{l}1 \\
2\end{array}$ & $\begin{array}{l}4 \\
6\end{array}$ & $\begin{array}{l}16 \\
24\end{array}$ & $\begin{array}{l}5 \\
5\end{array}$ & $\begin{array}{l}19.2 \\
19.2\end{array}$ & 0.8086 \\
\hline Skin toxicity (dermatitis) & $\begin{array}{l}1 \\
2 \\
3\end{array}$ & $\begin{array}{l}9 \\
9 \\
7\end{array}$ & $\begin{array}{l}36 \\
36 \\
28\end{array}$ & $\begin{array}{c}19 \\
4 \\
3\end{array}$ & $\begin{array}{l}73.1 \\
15.4 \\
11.5\end{array}$ & 0.03007 \\
\hline Mucous membrane (mucositis) & $\begin{array}{l}1 \\
2 \\
3\end{array}$ & $\begin{array}{c}1 \\
16 \\
8\end{array}$ & $\begin{array}{c}4 \\
64 \\
32\end{array}$ & $\begin{array}{c}10 \\
10 \\
6\end{array}$ & $\begin{array}{l}38.4 \\
38.4 \\
23.1\end{array}$ & 0.04845 \\
\hline Salivary gland (xerostomia) & $\begin{array}{l}1 \\
2\end{array}$ & $\begin{array}{c}7 \\
16\end{array}$ & $\begin{array}{l}24 \\
64\end{array}$ & $\begin{array}{c}6 \\
16\end{array}$ & $\begin{array}{l}23.1 \\
61.5\end{array}$ & 0.8150 \\
\hline Plarynx/Eosphagus (dysphagia) & $\begin{array}{l}1 \\
2 \\
3\end{array}$ & $\begin{array}{c}8 \\
10 \\
7\end{array}$ & $\begin{array}{l}32 \\
40 \\
28\end{array}$ & $\begin{array}{c}7 \\
10 \\
6\end{array}$ & $\begin{array}{l}26.7 \\
38.5 \\
23.1\end{array}$ & 0.9942 \\
\hline Subcutaneous tissue (neck edema) & $\begin{array}{l}1 \\
2\end{array}$ & $\begin{array}{c}10 \\
4\end{array}$ & $\begin{array}{l}40 \\
16\end{array}$ & $\begin{array}{l}9 \\
1\end{array}$ & $\begin{array}{c}34.6 \\
3.8\end{array}$ & 0.2693 \\
\hline Taste sensation (dysgeusia) & $\begin{array}{l}1 \\
2\end{array}$ & $\begin{array}{c}22 \\
3\end{array}$ & $\begin{array}{l}88 \\
12\end{array}$ & $\begin{array}{c}18 \\
3\end{array}$ & $\begin{array}{l}69.2 \\
11.5\end{array}$ & 0.8186 \\
\hline Weight loss & $\begin{array}{l}1 \\
2\end{array}$ & $\begin{array}{c}20 \\
4\end{array}$ & $\begin{array}{l}80 \\
16\end{array}$ & $\begin{array}{c}19 \\
3\end{array}$ & $\begin{array}{l}73.1 \\
11.5\end{array}$ & 0.7750 \\
\hline
\end{tabular}

Table 3: Acute adverse effects in both treatment arms.

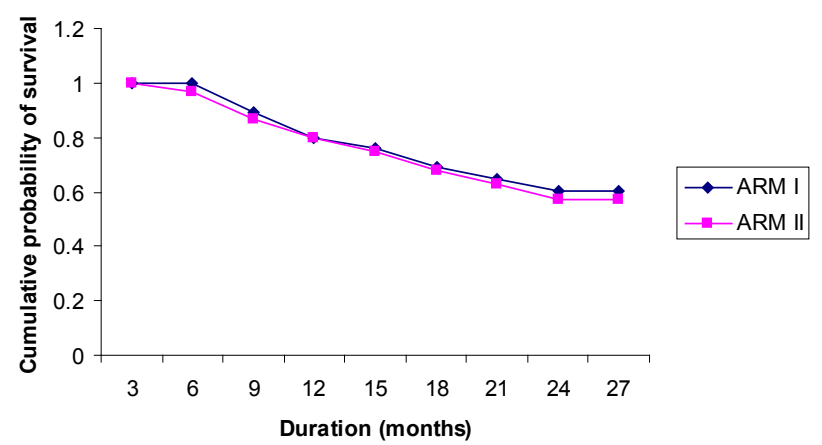

Figure 1: Cumulative probability of local-regional free survival in both treatment arms.

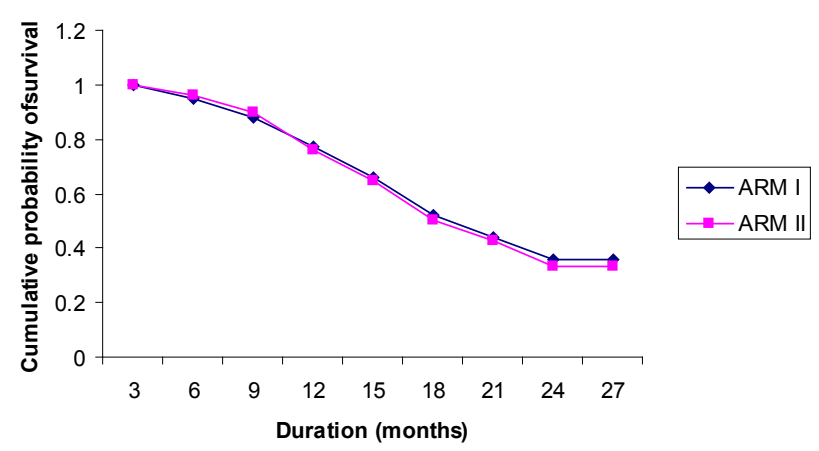

Figure 2: Cumulative probability of progression free survival in both treatment groups.

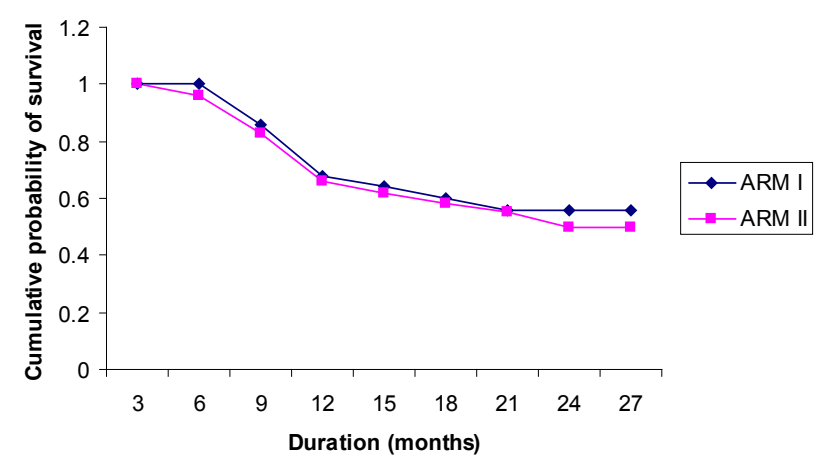

Figure 3: Cumulative probability of overall survival in both treatment arms.

\section{Discussion}

Locally advanced head and neck cancer is a great challenge for oncologists. The most aggressive non-surgical treatment is the combination of chemotherapy and radiation [15] however, grade 3 and 4 toxicity also significantly increase along with more intensive schedules [16].

This study was intended to compare concomitant chemoradiation using newer active agent paclitaxel in low dose weekly schedule versus most extensively used agent cisplatin with conventional radiation in locally advanced head and neck cancers.

In our study. No significant difference in efficacy was noted between both arms. This was true for the primary end point, response rates and locoregional control, as well as for other end points, progression-free survival and overall survival. Although some patients in our study in the paclitaxel arm sustained high local toxicity, mucositis and dermatitis, but it was tolerable and manageable. No dose limiting systemic toxicity was encountered in our study.

A $60 \%$ complete response was achieved with paclitaxel versus $53.8 \%$ with cisplatin in patients with highly advanced HNSCC. This response achieved in our study in the paclitaxel arm is comparable to those achieved with the regimens employed by Hoffmann et al. [17] and by Steinberg et al. [18]. RK Jain et al. reported $73 \%$ CR paclitaxel versus $64 \%$ with cisplatin in patient with HNSCC with the same regimen used in our research [19].

Hoffman et al. [17] studied the combination of conventional 
radiotherapy with weekly 1 hour infusion of paclitaxel in 18 patients with unresectable HNSCC. Paclitaxel was given at a starting dose of $20 \mathrm{mg} / \mathrm{m}^{2}$, and subsequent dose escalations of $10 \mathrm{mg} / \mathrm{m}^{2}$ were applied. Radiation therapy was administered over 6 to 7 weeks with $200 \mathrm{cGy}$ daily, up to total doses of 60-70 Gy. The maximum tolerated dose of paclitaxel in this setting was $30 \mathrm{mg} / \mathrm{m}^{2} /$ week, with mucositis being dose limiting.

Steinberg et al. [18] described a study in which 24 patients with stage III and IV HNSCC were administered radiotherapy (daily fractionation to total doses of 66 to $72 \mathrm{~Gy}$ ) in combination with paclitaxel given as 24-hour continuous infusions on days 1,22, and 43. Dose escalations of 75,90 and $105 \mathrm{mg} / \mathrm{m}^{2}$ were given. This regimen achieved CR of $72 \%$ at the primary site. The maximum-tolerated dose was retrospectively determined to be less than $75 \mathrm{mg} / \mathrm{m}^{2}$, because more than $50 \%$ of the patients developed febrile granulocytopenia at that dose. Significant local toxicities also were reported. Most notable of these were skin toxicity and grade 3 mucositis, necessitating enteral feeding tubes.

Lovey et al. [20] examined the use of low-dose paclitaxel concurrently with radiation for patients with locally advanced head and neck cancers. Twenty-six patients were treated with external beam radiotherapy and received concomitantly $2 \mathrm{mg} / \mathrm{m}^{2}$ paclitaxel three times a week. Beside an acceptable efficacy (RR: 65\%, 2-year overall survival $46 \%$ ) the treatment was well tolerated and resulted in a favorable toxicity profile. This regimen is resource effective and allows successive therapy if necessary, and therefore may serve as an alternative for patients in poor condition with locally advanced head and neck.

Tishler et al. [21] reported a study in which 14 patients with stage III and IV HNSCC were treated with paclitaxel administered at a dose of $100 \mathrm{mg} / \mathrm{m}^{2} / 3$ weeks), in combination with external beam radiation (daily fractionation to total doses of 60 to $70 \mathrm{~Gy}$ ). Of these 14 patients, 10 had received prior cisplatin, fluorouracil, and leucovorin. Overall, the concurrent therapy achieved a CR in 13 (92\%) of the 14 patients. Three of the 13 went on to develop recurrent disease (one with distant metastasis and two with local/regional disease). The major toxicities included grade 3,4 mucositis . Although the CR reported by Tishler et al. [21] was higher, comparisons of efficacy are difficult to interpret because $67 \%$ of those patients with a CR had received prior therapy.

Although no conclusions can be drawn as the optimal regimen based on this comparison of our study with the ones above, both concomitant chemoradiotherapy regimens were easily given in the outpatient clinic. The regimen based on paclitaxel was more effective; however, the difference was not enormous. Because of the shorter duration of follow-up and small sample size. Therefore, further studies are needed with large sample sizes and long duration of follow-up.

\section{References}

1. American cancer society (2010) Cancer Facts \& Figures Atlanta:American cancer society. Available at: http:// www.cancer.org/ downloads/ STT/Cancer Facts\&Figures 2010.

2. Elbolkainy MN (2005) Head and Neck cancer in: Topographic Pathology of Cancer.NCl, Cairo University (3rd edn) pp7.

3. Pignon JP, le Maître A, Maillard E, Bourhis J, MACH-NC Collaborative Group (2009) Meta-analysis of chemotherapy in head and neck cancer (MACHNC): an update on 93 randomised trials and 17,346 patients. Radiother Oncol 92: 4-14.

4. Jeremic B, Shibamoto Y, Milicic B, Nikolic N, Dagovic A, et al. (2000) Hyperfractionated radiation therapy with or without concurrent low-dose daily cisplatin in locally advanced squamous cell carcinoma of the head and neck: prospective randomized trial. J Clin Oncol 18: 1458-1464

5. Fountzilas G, Ciuleanu E, Dafni U, Plataniotis G, Kalogera-Fountzila A, et al. (2004) Concomitant radiochemotherapy vs radiotherapy alone in patients with head and neck cancer: a Hellenic Cooperative Oncology Group Phase III Study. Med Oncol 21: 95-107.

6. Huguenin P, Beer KT, Allal A, Rufibach K, Friedli C, et al. (2004) Concomitan cisplatin significantly improves locoregional control in advanced head and neck cancers treated with hyperfractionated radiotherapy. J Clin Oncol 22: 46654673.

7. Gupta T, Agarwal JP, Ghosh-Laskar S, Parikh PM, D'Cruz AK, et al. (2009) Radical radiotherapy with concurrent weekly cisplatin in loco-regionally advanced squamous cell carcinoma of the head and neck: a single-institution experience. Head Neck Oncol 1:17

8. Quon H, Leong T, Haselow R, Leipzig B, Cooper J, et al. (2010) Phase II Study of Radiation Therapy With or Without Cis-Platinum in Patients with Unresectable Squamous or Undifferentiated Carcinoma of the Head and Neck: An Intergroup Trial of the Eastern Cooperative Oncology Group (E2382). Int J Radiat Oncol Biol Phys [Epub ahead of print].

9. Adelstein DJ, Li Y, Adams GL, Wagner H, Kish JA, et al. (2003) An intergroup phase III comparison of standard radiation therapy and two schedules of concurrent chemoradiotherapy in patients with unresectable squamous cell head and neck cancer. J Clin Oncol 21: 92-98.

10. Homma A, Inamura N, Oridate N, Suzuki S, Hatakeyama H, et al. (2011) Concomitant weekly Cisplatin and radiotherapy for head and neck cancer. Jpn J Clin Oncol 41: 980-986.

11. Overgaard J, Hansen HS, Overgaard M, Bastholt L, Berthelsen A, et al. (1998) A randomized double-blind phase III study of nimorazole as a hypoxic radiosensitizer of primary radiotherapy in supraglotic larynx and pharynx carcinoma. Results of the Danish head and neck cancer study (DAHANCVA) protocol 5-85. Radiother Oncol 46: 135-146.

12. Wang $Y$, Wu KC, Zhao BX, Zhao X, Wang X, et al. (2011) A Nove Paclitaxel Microemulsion Containing a Reduced Amount of Cremophor EL: Pharmacokinetics, Biodistribution, and In Vivo Antitumor Efficacy and Safety. J Biomed Biotechnol 2011:854872. Epub 2011

13. Leonard CE, Chan DC, Chou TC, Kumar R, Bunn PA (1996) Paclitaxe enhances in vitro radiosensitivity of squamous carcinoma cell lines of the head and neck. Cancer Res 56: 5198-5204.

14. Srivastava RK, Mi QS, Hardwick JM, Longo DL et al. (1999) Deletion of the loop region of Bcl-2 completely blocks paclitaxel-induced apoptosis. Proc Natl Acad Sci USA 96: 3775-3780.

15. Bourhis J, Eschwege F (1996) Radiotherapy-chemotherapy combinations in head and neck squamous cell carcinoma: overview of randomized trials. Anticancer Res 16: 2397-2402.

16. Kies MS, Haraf DJ, Rosen F, Stenson K, List M, Brockstein B, et al. (2001) Concomitant infusional paclitaxel and fluorouracil, oral hydroxyurea, and hyperfractionated radiation for locally advanced squanous head and neck cancer. J Clin Oncol 19: 1961-1969.

17. Hoffmann W, Belka C, Schmidberger H, Budach W, Bochtler H, et al. (1997) Radiotherapy and concomitant weekly 1-hour infusion of paclitaxel in the treatment of head and neck cancer-results from a phase I trial. Inbt J Radiat Oncol Biol Phys 38: 691-696.

18. Steinberg L, Hassan M, Olmsted L, Sharan V, Stepnick D, et al. (1997) A phase I trial of radiotherapy and simultaneous 24-hour paclitaxel in patients with locally advanced head and neck squamous cell carcinoma. Semin Oncol 24: S19-51-56.

19. Jain RK, Kirar P, Gupta G, Dubey S, Gupta SK, et al. (2009) A comparative study of low dose $\mathrm{P}$ weekly paclitaxel versus cisplatin with concurrent radiation in the treatment of locally advanced head and neck cancer. Indian $\mathrm{J}$ Cancer 46: $50-53$

20. Lövey J, Koronczay K, Remenár E, Csuka O, Németh G (2003) Radiotherapy and concurrent low-dose paclitaxel in locally advanced head and neck cancer. Radiother Oncol 68: 171-174

21. Tishler RB, Busse PM, Norris CM, Rossi R, Poulin M, et al. (1999) An initia experience using concurrent paclitaxel and radiation in the treatment of head and neck malignancies. Int J Radiat Oncol Biol Phys 43: 1001-1008. 